\title{
Effect of Effective Microorganisms (EM) and Potassium Sulphate on Productivity and Fruit Quality of "Hayany" Date Palm Grown Under Salinity Stress
}

\author{
Amro S.M. Salama, Omima M. El- Sayed, Osama H.M. El Gammal \\ Plant Production Department, Desert Research Center, Cairo, Egypt
}

\begin{abstract}
An experiment trial was carried out in a private orchard at Ras-Sudr, South Sinai Governorate, Egypt, during the two successive seasons of 2012 and 2013 to study the effect of effective microorganisms biofertilizer (EM) at 60 and $90 \mathrm{ml} / \mathrm{palm} / \mathrm{year}$ and potassium sulphate at 1 and $1.5 \mathrm{~kg} / \mathrm{palm} / \mathrm{year}$ as well as their combinations in alleviating the adverse effect of salinity on productivity of "Hayany" date palm. From the obtained results showed that it is preferable to add EM at $90 \mathrm{ml} / \mathrm{palm} /$ year combined with potassium sulphate at $1.5 \mathrm{~kg} / \mathrm{palm} / \mathrm{year}$ as a soil application divided into three equal doses applied at three times a year to enhance leaf chlorophyll content, fruit set percentage, retained fruit percentage, yield, fruit quality and leaf minerals content of "Hayany" date palm.
\end{abstract}

Key words: EM biofertilizer - Potassium sulphate - "Hayany" cv. date palm - Salinity stress -Yield - fruit quality - leaf chlorophyll - leaf minerals content.

\section{Introduction}

Date palm is the most important fruit species in Egypt and it plays an important role in the economic and social life of the people in Egypt. Also it is considered a symbol of life in desert. Furthermore, it tolerates high temperature, drought and salinity more than many other fruit crops (FAO, 1982; Lunde, 1978 and Ramoliya and Pandey, 2003).

Salinity stress is a major abiotic stress adversely reduced growth and productivity of date palm (Ayers and Westcot, 1985 and Erskine et al., 2004). Salinity stress induces an impact growth and productivity of date palm, and decreases the net photosynthesis and chlorophyll levels of date palm (Al-Abdoulhadi et al., 2012). Date palm exhibits a high degree of salinity tolerance (Zaid and De Wet, 2002).

Date palm cultivar "Hayany" is one of the most important soft date cultivars in Egypt from the economical standpoint also, it is highly sensitive to salinity than "Sewy" and "Zaghloul" cultivars (El-Khawaga, 2013).

Salinity induces osmotic stress, ionic imbalance, ion toxicity and nutrient deficiency regarding plant growth (Parida and Das, 2005). Also salinity is involved as an oxidative stress which produces reactive oxygen species (free radicals) like superoxidase, hydroxyl radical, hydrogen peroxide and singlet oxygen that involved in promoting membrane lipid peroxidation as well as membrane leakage (Ashraf, 2004 and Gunes et al., 2007), and these reactive oxygen species finally scratch chloroplast and mitochondria by distracting their cellular structures (Mittler, 2002).

Furthermore, growers have mistakenly believed that date palm does not require much attention, while the successful orchard management practices are the way to high yield of good fruit quality. One of the best tools of horticultural practices is fertilization. The use of fertilizers to increase yield is an important factor in all agricultural systems (Dong et al., 2005).

There was a technology introduced by professor Teruo Higa, University of Ryukyus, Okinawa, Japan, who isolated some beneficial micro-organisms from the soil and called them effective microorganism (EM) and marketed by EM Research Organization (Higa, 1986).

In addition, EM contains selected species of microorganisms including three principal types of organisms namely lactic acid bacteria, yeast actinomyces and photosynthetic bacteria that are commonly found in soils (Higa, 1991). All of these are mutually compatible with one another and can coexist in liquid culture (Higa and Wididana, 1991). The basic purpose of EM is the restoration of healthy ecosystem in both soil and water by using genus of microorganisms which are found in nature. Generally, EM technology has been adopted globally and is recognized as a powerful and effective tool in both agriculture and horticulture for crop and animal production systems (Chamberlain et al., 1997). EM is used to improve soil fertility and plant growing conditions (Higa, 1991 and Higa and Wididana, 1991).

Furthermore, using of Baikal EM1 in Russia (this preparation was given the name of Baikal EM1) mitigate the effects of salt stress and improve the salt resistance of (Gleditschia triacanthos L. and Abies nordmanniana Karst) seedlings (Allahverdiyev et al., 2011). 
Osman et al. (2011) mentioned that effective microorganisms (EM1) application at $1.0 \mathrm{~cm}^{3} /$ palm gave the best results in yield and fruit quality of "Bartamuda" date palm. Moreover, El-Khawaga (2013) reported that EM application as anti-salinity improved growth, yield and fruit quality of date palm cultivars "Sewy", "Zaghloul" and "Hayany".

In additions, potassium has an important roles in plants resistance to environmental stresses, pests and pathogens (Marschner, 1993), and it is needed for fruit development of fruit (Marschner, 1995). Potassium activates the enzymes involving in sugar biosynthesis and helps in translocation of sugars (Archer, 1988), and this element affects the quantity and quality of dates (El- Deeb et al., 2000).

Potassium has positive role in plant growth under saline conditions hence this element plays an essential role in photosynthesis and osmoregulatory (Nelson, 1978), and it is required for physiological processes such as activation of enzymes, regulation of osmotic pressure and stomata movement (Gollback et al., 2003). It reduces the excess uptake of ions such as sodium and iron under saline stress therefore; potassium plays a particular role in contributing to the survival of crop plants under environmental stress conditions (Marschner, 1995 and Mengel and Kirkby, 2001). Beside, potassium reduces the production of reactive oxygen species like superoxidase, hydroxyl radical, hydrogen peroxide and singlet oxygen (Cakmak, 2005). Also potassium fertilization alleviates the effect of salinity by enhancing activities of antioxidant enzymes (Zheng et al., 2008).

Generally, potassium plays an important role in controlling cell water content and carbohydrates biosynthesis and mobilization in plant tissues, consequently carbohydrates play a serious role in fruit set (Harhash and Abdel-Nasser, 2007; Khayyat et al., 2007; Shahin, 2007; Harhash and Abdel-Nasser 2010). Moreover, potassium plays a key role in $\mathrm{N}$ uptake and translocation from roots to vegetative growth (Cushnahan et al., 1995). Furthermore, the ability of plants to tolerate salinity depends on the potassium status in leaves (Maathuis and Amtmann, 1999), and uptake of potassium by date palm seedling increased with the increase in salinity (Hassan and El-Samnoudi, 1998).

In this concern, Harhash and Abdel-Nasser (2007) on "Zaghloul" date palm; Shahin (2007) on "Khalas" date palm, reported that potassium fertilization improved yield and fruit quality parameters of the aforementioned date palm cultivars.

Moreover, Osman (2010) showed that, potassium sulphate fertilization at $4.5 \mathrm{~kg} / \mathrm{palm}$ applied at three doses in March, June and September gave the highest palm yield, fruit quality and leaf mineral content of "Bartamoda" cultivar date palm. Furthermore, fertilization with potassium sulphate and /or combined with compost, yeast and EM alleviated salinity stress and improved leaf characters, growth, yield, fruit quality and leaf mineral content of orange cv. Valencia under salt stress (Abdelaal et al., 2013).

The aim of this investigation is to study the effect of EM and potassium sulphate on leaf total chlorophyll content, fruit set percentage, yield, fruit quality and leaf mineral content of Hayany date palm cultivated in sandy soil under salinity stress at Ras - Sudr conditions, Egypt.

\section{Material and Methods}

This study was carried out during two successive seasons of 2012 and 2013 in a private orchard, at Ras-Sudr, South Sinai Governorate, Egypt on "Hayany" date palm of eight years old grown in sandy soil, and spaced $7 \times 7 \mathrm{~m}$ apart under drip irrigation system from a well. Physical and chemical analyses of the experimental soil are shown in Table 1. Meanwhile, the chemical analysis of the used water for irrigation is recorded in Table 2. Selected palms were irrigated according to the recommended program (including the rate and time) which used in the district.

Fifty four female palm healthy, nearly uniform in shape, size and productivity, received the same horticultural practices were treated with the effective microorganisms (EM) biofertilizer and potassium sulphate $\left(48 \% \mathrm{~K}_{2} \mathrm{O}\right)$ fertilizer as soil application as follows:

1- Control "untreated".

2- $\quad$ EM at $60 \mathrm{ml} / \mathrm{palm} / \mathrm{year}$

3- $\quad$ EM at $90 \mathrm{ml} /$ palm/year

4- Potassium sulphate at $1 \mathrm{~kg} / \mathrm{palm} /$ year

5- Potassium sulphate at $1.5 \mathrm{~kg} / \mathrm{palm} /$ year

6- $\quad$ EM at $60 \mathrm{ml}$ combined with Potassium sulphate at $1 \mathrm{~kg} / \mathrm{palm} / \mathrm{year}$

7- $\quad$ EM at $90 \mathrm{ml}$ combined with Potassium sulphate at $1 \mathrm{~kg} / \mathrm{palm} / \mathrm{year}$

8- $\quad$ EM at $60 \mathrm{ml}$ combined with Potassium sulphate) at $1.5 \mathrm{~kg} / \mathrm{palm} / \mathrm{year}$

9- $\quad \mathrm{EM}$ at $90 \mathrm{ml}$ combined with Potassium sulphate at $1.5 \mathrm{~kg} / \mathrm{palm} /$ year 
Effect of Effective Microorganismis (Em) and Potassium Sulphate on Productivity and ...

Table 1. Analysis of the experimental soil at Ras-Sudr, South Sinai Governorate, Egypt.

\begin{tabular}{|c|c|c|c|c|c|c|c|c|c|c|c|c|}
\hline \multirow{2}{*}{$\begin{array}{l}\text { Soll } \\
\text { depth } \\
(\mathrm{cm})\end{array}$} & \multirow{2}{*}{$\begin{array}{l}\text { Textur } \\
\text { e class }\end{array}$} & \multirow{2}{*}{$\begin{array}{c}\text { pH sol } \\
\text { past }\end{array}$} & \multirow{2}{*}{$\begin{array}{l}\text { E.Ce } \\
\left(\mathrm{dSm}^{-4}\right)\end{array}$} & \multirow{2}{*}{$\begin{array}{c}\text { Organi } \\
c \\
\text { matter } \\
\%\end{array}$} & \multicolumn{4}{|c|}{ Soluble cations (mequiv./1) } & \multicolumn{4}{|c|}{ Soluble anions (mequiv./1) } \\
\hline & & & & & $\mathrm{Ca}^{--}$ & $\mathrm{K}^{-}$ & $\mathrm{Na}^{-}$ & $\mathrm{Mg}^{-2}$ & $\mathrm{Cl}^{\circ}$ & $\mathrm{So}_{4}$ & $\mathrm{HCO}_{3}$ & $\mathrm{Cos}$ \\
\hline 0.30 & Sand & 7.28 & 9.1 & 0.53 & 16.2 & 1.3 & 50.4 & 23.1 & 54.5 & 33.9 & 2.5 & $\cdots$ \\
\hline $30-60^{\circ}$ & Sand & 7.16 & 8.6 & $0.55^{-}$ & 15.3 & 1.23 & 47.7 & 21.9 & 51.5 & 32.1 & 2.4 & - \\
\hline
\end{tabular}

Table 2. Chemical analysis of water used for irrigation at the experimental orchard, at Ras-Sudr, South Sinai Governorate, Egypt.

\begin{tabular}{|c|c|c|c|c|c|c|c|c|c|}
\hline \multirow[t]{2}{*}{$\mathrm{PH}$} & \multirow[t]{2}{*}{ E.Ce $(\mathrm{dSm}-1)$} & \multicolumn{4}{|c|}{ Soluble cations (me/l) } & \multicolumn{4}{|c|}{ soluble anions $(\mathrm{me} / \mathrm{l})$} \\
\hline & & $\mathrm{Ca}^{++}$ & $\mathrm{Mg}^{++}$ & $\mathrm{Na}^{+}$ & $\mathrm{K}^{+}$ & $\mathrm{Co}_{3}=$ & $\mathrm{HCO}_{3}$ & $\mathrm{Cl}^{-}$ & $\mathrm{So}_{4}{ }^{=}$ \\
\hline 7.43 & 8.1 & 14.4 & 20.6 & 44.9 & 1.16 & -- & 2.3 & 48.5 & 30.2 \\
\hline
\end{tabular}

The experiment was designed as randomized complete block design with three replicates for each treatment and each replicate was represented by two palms.

Soil application of EM biofertilizer treatments were divided into three equal doses applied on February, $1^{\text {st }}$, May, $1^{\text {st }}$ and July, $1^{\text {st }}$ in each season and soil application of potassium sulphate treatments were divided into two equal doses applied on May, $1^{\text {st }}$ and July, $1^{\text {st }}$ in each season.

The ordinary fertilization program which used in the district was $25 \mathrm{~kg} / \mathrm{palm}$ of sheep manure added in December, $1.5 \mathrm{~kg} /$ palm of triple calcium super phosphate $\left(45 \% \mathrm{P}_{2} \mathrm{O}_{5}\right)$ broadcasted on the soil surface through the whole area during December and $5 \mathrm{~kg}$ ammonium sulphate/palm $(20.5 \% \mathrm{~N})$ divided into three equal doses applied on February, $1^{\text {st }}$, May, $1^{\text {st }}$ and July, $1^{\text {st }}$. broadcasted on the soil surface through the whole area.

The response of "Hayany" date palms to EM, $\left(\mathrm{K}_{2} \mathrm{SO}_{4}\right)$ and their combinations were evaluated through the following determinations.

\subsection{Leaf total chlorophyll content}

Leaf total chlorophyll content was determined by Minolta chlorophyll meter SPAD-502.

\subsection{Retained fruit percentage}

The retained fruit percentage was calculated at the harvest time on September, $1^{\text {st }}$ according to Soliman and El Kosary (2002) formula as follows:

$\begin{aligned} \text { The retained fruit percentage }= & \text { Total number of retained fruits per bunch } \\ \text { Total number of the nodes per bunch } & \end{aligned}$

\subsection{Yield kg/palm}

Total number of the nodes per bunch

In both seasons, dates were harvested at the first of September when fruits reached Khalal stage and the average fruit yield and bunch weight was recorded in Kilograms.

\subsection{Fruit physical and chemical properties}

Forty fruits were taken at harvest from each treated palm at Khalal stage (full mature, crunchy and red in color) from each bunch to determine the following physical and chemical properties $\mathrm{i}$. e. fruit weight (g), fruit volume $\left(\mathrm{cm}^{3}\right)$, fruit length $(\mathrm{cm})$, fruit diameter $(\mathrm{cm})$, pulp weight $(\mathrm{g})$, pulp dry matter $(\%)$, seed weight $(\mathrm{g})$, total soluble solids content (T.S.S.) which was determined by Hand refractometer, percentage of total acidity as $g$ citric acid / $100 \mathrm{~g}$ f.wt., T.S.S./Acid ratio and total sugars $(\%) \mathrm{g} / 100 \mathrm{~g}$ f.wt., which were determined according to A.O.A.C. (1995).

\subsection{Leaf minerals content}

To determine leaf mineral content (N, P, K, Ca and Mg), leaf samples were taken during November and washed with tap water then with distilled water to remove the dust. After washing, they were dried in an electric oven at $70^{\circ} \mathrm{c}$ for 72 hours. The dried leaves were ground, digested and prepared for analysis using the method described by Parkinson and Allen (1975). Total nitrogen was determined by the semi-micro kjeldahl method (Bremner 1965). Phosphorus was estimated by the method of Chapman and Pratt (1961). Potassium was determined by the flame-photometer according to Jackson (1958). Calcium and magnesium were determined by titration against versente solution (Na EDTA) according to (Chapman and Pratt, 1961).

\section{Statistical analysis}

The obtained data in 2012 and 2013 seasons were subjected to analysis of variance according to Clarke and Kempson (1997) using MSTAT-C program version 7 (1990). Means were differentiated using multiple Range test at the 0.05 level (Duncan, 1955). 


\subsection{Leaf total chlorophyll content}

\section{Results and Discussion}

Table 3, illustrates that all tested treatments induced significant differences in leaf total chlorophyll content of "Hayany" date palms. The highest leaf total chlorophyll content was achieved by $90 \mathrm{ml} / \mathrm{palm}$ EM combined with potassium sulphate at $1.5 \mathrm{~kg} / \mathrm{palm}$ treatment (80.1 and 78.6), against (56.1 and 58.2) for the control treatment both seasons, respectively.

The beneficial effect of EM application on alleviating the adverse effect of salinity on leaf total chlorophyll content might be attributed to their effect on enhancing organic matter, lowering soil $\mathrm{pH}$ as well as increased the uptake of water and nutrients (Higa, 1991; Higa and Wididana, 1991), enhancing soil fertility (Formowitz et al., 2007 and Ibrahim, 2012). Also, EM is restoration of healthy ecosystem in soil (Higa, 1991). Moreover, EM application increased number of the soil microflora i.e. total bacteria, total actinomyces and total fungi which are precursor of indole acetic acid and gibberellins that leads to improve growth of root system, reflected on enhancing the uptake of nutrients thereby improving plant health under salinity stress.

These results are in agreement with these obtained by Abdalaal et al., (2013) on orange trees.

The enhancement effect of potassium sulphate on alleviating the adverse effect of salinity on leaf total chlorophyll content may be attributed to the fact that potassium plays an essential role in photosynthesis and osmoregulatory (Nelson, 1978), it is required for physiological processes such as activation of enzymes, regulation of osmotic pressure and stomata movement (Gollback et al., 2003), also it reduces the production of reactive oxygen species (Cakmak, 2005), by enhancing activities of antioxidant enzymes (Zheng et al., 2008). As well as it activates the enzymes involved in sugar biosynthesis and helps in translocation of sugars (Archer, 1988). However, it reduces excess uptake of ions such as sodium under saline stress. All these together reflected on alleviating the adverse effect of salinity stress on date palm and improved leaf total chlorophyll content.

The obtained results regarding the effect of potassium sulphate application on leaf total chlorophyll content are in line with the findings of Osman et al. (2011) on "Bartamuda" date palm; Abdelaal et al. (2013) on orange trees.

Table 3. Effect of EM and potassium sulphate soil application on leaf total chlorophyll content, retained fruit $(\%)$ and yield of "Hayany" date palms (2012 \&2013 seasons)

\begin{tabular}{|c|c|c|c|c|c|c|}
\hline \multirow[t]{2}{*}{ Treatments } & \multicolumn{2}{|c|}{ Total chlorophyll } & \multicolumn{2}{|c|}{ Retained fruit $(\%)$} & \multicolumn{2}{|c|}{ Yield $(\mathrm{kg}) /$ palm } \\
\hline & 2012 & 2013 & 2012 & 2013 & 2012 & 2013 \\
\hline Control " untreated" & $56.1 \mathrm{~g}$ & $58.2 \mathrm{i}$ & $30.50 \mathrm{c}$ & $30.06 \mathrm{e}$ & $50.06 \mathrm{~d}$ & $49.96 \mathrm{f}$ \\
\hline $\mathrm{EM}$ at $60 \mathrm{ml} / \mathrm{palm}$ & $59.9 \mathrm{f}$ & $63.9 \mathrm{~h}$ & $31.43 \mathrm{bc}$ & $31.23 \mathrm{~d}$ & $52.26 \mathrm{~cd}$ & $53.46 \mathrm{e}$ \\
\hline $\mathrm{EM}$ at $90 \mathrm{ml} / \mathrm{palm}$ & $61.3 \mathrm{f}$ & $66.1 \mathrm{~g}$ & $32.36 \mathrm{bc}$ & $32.13 \mathrm{c}$ & $56.26 \mathrm{abc}$ & $57.10 \mathrm{~d}$ \\
\hline $\mathrm{K}_{2} \mathrm{SO}_{4}$ at $1 \mathrm{~kg} /$ palm & $63.3 \mathrm{e}$ & $69.1 \mathrm{f}$ & $32.06 \mathrm{bc}$ & $32.10 \mathrm{c}$ & $53.43 \mathrm{bcd}$ & $58.06 \mathrm{~d}$ \\
\hline $\mathrm{K}_{2} \mathrm{SO}_{4}$ at $1.5 \mathrm{~kg} / \mathrm{palm}$ & $69.0 \mathrm{~d}$ & $71.2 \mathrm{e}$ & $32.46 \mathrm{bc}$ & $32.20 \mathrm{c}$ & $56.36 \mathrm{abc}$ & $60.53 \mathrm{c}$ \\
\hline $\mathrm{EM}$ at $60 \mathrm{ml}+\mathrm{K}_{2} \mathrm{SO}_{4}$ at $1 \mathrm{~kg} /$ palm & $72.1 \mathrm{c}$ & $73.6 \mathrm{~d}$ & $33.00 \mathrm{abc}$ & $35.10 \mathrm{~b}$ & $58.53 \mathrm{ab}$ & $61.86 \mathrm{c}$ \\
\hline $\mathrm{EM}$ at $90 \mathrm{ml}+\mathrm{K}_{2} \mathrm{SO}_{4}$ at $1 \mathrm{~kg} / \mathrm{palm}$ & $73.3 \mathrm{c}$ & $75.5 \mathrm{c}$ & $33.60 \mathrm{ab}$ & $36.10 \mathrm{a}$ & $58.4 \mathrm{ab}$ & $62.40 \mathrm{c}$ \\
\hline $\mathrm{EM}$ at $60 \mathrm{ml}+\mathrm{K}_{2} \mathrm{SO}_{4}$ at $1.5 \mathrm{~kg} / \mathrm{palm}$ & $75.7 \mathrm{~b}$ & $76.8 \mathrm{~b}$ & $35.03 \mathrm{a}$ & $36.10 \mathrm{a}$ & $59.56 \mathrm{a}$ & $66.70 \mathrm{~b}$ \\
\hline $\mathrm{EM}$ at $90 \mathrm{ml}+\mathrm{K}_{2} \mathrm{SO}_{4}$ at $1.5 \mathrm{~kg} / \mathrm{palm}$ & $80.1 \mathrm{a}$ & $78.6 \mathrm{a}$ & $35.16 \mathrm{a}$ & $36.13 \mathrm{a}$ & $59.76 \mathrm{a}$ & $70.33 \mathrm{a}$ \\
\hline
\end{tabular}

Means within each column followed by the same letter (s) are not significantly different at $5 \%$ level.

\subsection{Retained fruit (\%)}

Table 3, shows that 60 and $90 \mathrm{ml} / \mathrm{palm}$ EM combined with potassium sulphate at $1.5 \mathrm{~kg} / \mathrm{palm}$ fertilizers gave the highest positive effect on retained fruit percentage in both seasons.

\subsection{Yield (kg)/palm}

Table 3, demonstrates that all tested treatments significantly increased yield as compared with the control treatment in both seasons of this study. Generally, $90 \mathrm{ml} / \mathrm{palm}$ EM combined with potassium sulphate at $1.5 \mathrm{~kg} / \mathrm{palm}$ gave the highest yield $(59.76$ and $70.33 \mathrm{~kg} / \mathrm{palm})$ against the control treatment (50.06 and 49.96 $\mathrm{kg} / \mathrm{palm}$ ) in both seasons, respectively.

\subsection{Bunch weight $(\mathbf{k g})$}

Table 4, indicates that all EM and potassium sulphate as well as their combinations produced positive effect on bunch weight as compared with the control. Shortly, $90 \mathrm{ml} / \mathrm{palm}$ EM combined with potassium sulphate at 1.5 $\mathrm{kg} / \mathrm{palm}$ gave the highest positive effect on bunch weight as compared with the control as well as tested other treatments. 
Effect of Effective Microorganismis (Em) and Potassium Sulphate on Productivity and ...

Table 4. Effect of EM and potassium sulphate soil application on bunch weight and some fruit physical properties of "Hayany" date palms (2012 \&2013 seasons)

\begin{tabular}{|c|c|c|c|c|c|c|}
\hline \multirow[t]{2}{*}{ Treatments } & \multicolumn{2}{|c|}{ bunch weight $(\mathrm{kg})$} & \multicolumn{2}{|c|}{ Fruit weight $(\mathrm{g})$} & \multicolumn{2}{|c|}{ Fruit volume $\left(\mathrm{cm}^{3}\right)$} \\
\hline & 2012 & 2013 & 2012 & 2013 & 2012 & 2013 \\
\hline Control " untreated" & $16.6 \mathrm{~d}$ & $16.5 \mathrm{f}$ & $8.5 \mathrm{~g}$ & $8.0 \mathrm{f}$ & $8.8 \mathrm{f}$ & $8.3 \mathrm{f}$ \\
\hline $\mathrm{EM}$ at $60 \mathrm{ml} / \mathrm{palm}$ & $17.4 \mathrm{~cd}$ & $17.6 \mathrm{e}$ & $9.1 \mathrm{fg}$ & 8.6 ef & $9.3 \mathrm{ef}$ & 9.1 ef \\
\hline $\mathrm{EM}$ at $90 \mathrm{ml} / \mathrm{palm}$ & $18.7 \mathrm{bc}$ & $19.0 \mathrm{~d}$ & $10.0 \mathrm{de}$ & $9.4 \mathrm{e}$ & $10.3 \mathrm{e}$ & $9.6 \mathrm{e}$ \\
\hline $\mathrm{K}_{2} \mathrm{SO}_{4}$ at $1 \mathrm{~kg} / \mathrm{palm}$ & $17.8 \mathrm{~cd}$ & $19.3 \mathrm{~d}$ & $9.5 \mathrm{ef}$ & 8.9 ef & 9.8 ef & $9.3 \mathrm{e}$ \\
\hline $\mathrm{K}_{2} \mathrm{SO}_{4}$ at $1.5 \mathrm{~kg} / \mathrm{palm}$ & $18.7 \mathrm{bc}$ & $20.1 \mathrm{c}$ & $10.7 \mathrm{~d}$ & $10.4 \mathrm{~d}$ & $11.3 \mathrm{c}$ & $11.0 \mathrm{~d}$ \\
\hline $\mathrm{EM}$ at $60 \mathrm{ml}+\mathrm{K}_{2} \mathrm{SO}_{4}$ at $1 \mathrm{~kg} /$ palm & $19.5 \mathrm{ab}$ & $20.6 \mathrm{c}$ & $12.3 \mathrm{c}$ & $11.5 \mathrm{c}$ & $12.8 \mathrm{c}$ & $12.1 \mathrm{c}$ \\
\hline $\mathrm{EM}$ at $90 \mathrm{ml}+\mathrm{K}_{2} \mathrm{SO}_{4}$ at $1 \mathrm{~kg} / \mathrm{palm}$ & $19.4 \mathrm{ab}$ & $20.8 \mathrm{c}$ & $12.9 \mathrm{c}$ & $12.2 \mathrm{bc}$ & $13.3 \mathrm{bc}$ & $12.8 \mathrm{bc}$ \\
\hline $\mathrm{EM}$ at $60 \mathrm{ml}+\mathrm{K}_{2} \mathrm{SO}_{4}$ at $1.5 \mathrm{~kg} / \mathrm{palm}$ & $19.9 \mathrm{ab}$ & $22.3 \mathrm{~b}$ & $13.8 \mathrm{~b}$ & $13.1 \mathrm{ab}$ & $14.1 \mathrm{~b}$ & $13.6 \mathrm{~b}$ \\
\hline $\mathrm{EM}$ at $90 \mathrm{ml}+\mathrm{K}_{2} \mathrm{SO}_{4}$ at $1.5 \mathrm{~kg} / \mathrm{palm}$ & $20.9 \mathrm{a}$ & $23.4 \mathrm{a}$ & $14.9 \mathrm{a}$ & $13.8 \mathrm{a}$ & $15.3 \mathrm{a}$ & $14.6 \mathrm{a}$ \\
\hline
\end{tabular}

Means within each column followed by the same letter (s) are not significantly different at $5 \%$ level.

The enhancement effect of EM on alleviating the adverse effect of salinity on yield and bunch weight may be attributed to the increase of leaf total chlorophyll content which leads to more carbohydrates production through photosynthesis process and increasing vegetative growth and consequently improved fruit set percentage, retained fruit percentage and finally improved yield and bunch weight. Also, EM have beneficial effect on enhancing organic matter, lowering soil $\mathrm{pH}$ as well as increased the uptake of water and nutrients (Higa, 1991; Higa and Wididana, 1991), and enhanced soil fertility (Formowitz et al., 2007 and Ibrahim, 2012).EM is restoration of healthy ecosystem in soil (Higa, 1991). Moreover, EM application increased number of the soil microflora i.e. total bacteria, total actinomyces and total fungi which are precursors indole acetic acid and gibberellins leads to improvement growth of root system that reflected on enhancing the uptake of nutrients thereby improving plant health under salinity stress consequently improved tree fruiting parameters and yield.

The obtained results regarding the effect of EM application on yield and bunch weight are in line with the findings of Osman et al. (2011) on "Bartamuda" date palm; Adbelaal et al. (2013) on orange; El-Khawaga (2013) on date palm cultivars "Sewy", "Zaghloul" and "Hayany".

The enhancement effect of potassium sulphate on alleviating the adverse effect of salinity on yield and bunch weight may be attributed to that potassium reduces the excess uptake of ions such as sodium under saline stress. Also it play a key role in $\mathrm{N}$ uptake and translocation from roots to vegetative growth (Cushnahan et al., 1995).Moreover, potassium plays an essential role in photosynthesis and osmoregulatory (Nelson, 1978), and it is required for physiological processes such as activation of enzymes, regulation of osmotic pressure and stomata movement (Gollback et al., 2003). Moreover, it activates the enzymes involved in sugar biosynthesis and helps in translocation of sugars (Archer, 1988). In addition, potassium showed an important role in controlling cell water content and carbohydrates biosynthesis and mobilization in plant tissues, which reflected on yield and increase fruit weight.

The obtained results regarding the effect of potassium sulphate application on yield and bunch weight are in harmony with the findings of Harhash and Abdel-Nasser (2007) on date palm cultivar "Zaghloul"; Harhash and Abdel-Nasser (2010) on date palm cultivar "Khalas"; Osman (2010) on date palm cultivar " Bartamoda"; Al-Obeed et al. (2013) on date palm cultivar "Khalas".

\subsection{Fruit physical and chemical properties}

\subsubsection{Fruit weight (g)}

Table 4 , indicates that all tested fertilizers produced statistically positive effect on fruit weight as compared with the control of both seasons. However, the heaviest fruits were produced by $90 \mathrm{ml} / \mathrm{palm} \mathrm{EM}$ combined with potassium sulphate at $1.5 \mathrm{~kg} / \mathrm{palm}$ treatment $(14.9$ and $13.8 \mathrm{~g})$. On the other hand, the control treatment recorded the lowest values $(8.5$ and $8.0 \mathrm{~g})$ in both seasons, respectively.

\subsubsection{Fruit volume $\left(\mathrm{cm}^{3}\right)$}

Table 4, illustrates that all tested treatments scored statistically higher values of fruit volume as compared with the control treatment in both seasons of study. Generally, $90 \mathrm{ml} / \mathrm{palm}$ EM enriched with potassium sulphate at $1.5 \mathrm{~kg} / \mathrm{palm}$ induced the highest fruit volume $(15.3$ and $14.6 \mathrm{~cm} 3)$ against $(8.8$ and 8.3 $\mathrm{cm} 3$ ) for the control in both seasons, respectively.

\subsubsection{Fruit length $(\mathrm{cm})$}

Tabulated data demonstrate that all tested fertilizers treatments exerted higher positive effect on fruit length as compared with control treatment. However, $90 \mathrm{ml} / \mathrm{palm}$ EM supplemented with potassium sulphate at $1.5 \mathrm{~kg} / \mathrm{palm}$ proved to be the most efficient treatment in this respect (Table 5). 


\subsubsection{Fruit diameter (cm)}

Table 5, reveals that all tested EM and potassium sulphate treatments induced similar and higher positive effect on fruit diameter as compared with the control treatment. Briefly, 60 and $90 \mathrm{ml} / \mathrm{palm}$ EM supported with potassium sulphate at $1.5 \mathrm{~kg} / \mathrm{palm}$ treatments gave the highest positive effect on fruit diameter as compared with the control treatment.

\subsubsection{Pulp weight (g)}

Table 5, indicates that all tested fertilizer treatments produced higher positive effect on pulp weight as compared with the control treatment. In summary, $90 \mathrm{ml} / \mathrm{palm}$ EM combined with potassium sulphate at 1.5 $\mathrm{kg} / \mathrm{palm}$ treatment proved to be the most efficient treatment in this concern.

\subsubsection{Pulp dry matter (\%)}

Table 6, reveals that $90 \mathrm{ml} / \mathrm{palm}$ EM combined with potassium sulphate at $1.5 \mathrm{~kg} / \mathrm{palm}$ treatment proved to be the most efficient treatment in this respect.

\subsubsection{Seed weight (g)}

Table 6, demonstrates that $60 \mathrm{ml} / \mathrm{palm}$ EM combined with potassium sulphate at $1 \mathrm{~kg} / \mathrm{palm}$ treatment in the first season and $90 \mathrm{ml} / \mathrm{palm}$ EM combined with potassium sulphate at $1 \mathrm{~kg} /$ palm in the second season gave a high positive effect on seed weight in this study.

\subsubsection{Fruit T.S.S. $(\%)$}

Table 6, illustrates that all tested treatments exerted similar and higher positive effect on fruit T.S.S. content as compared with control treatment. However, 60 and $90 \mathrm{ml} / \mathrm{palm}$ EM provided with potassium sulphate at $1.5 \mathrm{~kg} / \mathrm{palm}$ treatment proved to be the most efficient treatment in this concern.

Table 5. Effect of EM and potassium sulphate soil application on some fruit physical properties of "Hayany" date palms (2012 \&2013 seasons)

\begin{tabular}{lllllll}
\hline \multicolumn{1}{c}{ Treatments } & \multicolumn{2}{l}{ Fruit length $(\mathrm{cm})$} & \multicolumn{2}{l}{ Fruit diameter $(\mathrm{cm})$} & \multicolumn{2}{l}{ Pulp weight $(\mathrm{g})$} \\
\hline \multicolumn{1}{c}{ Control " untreated" } & 2012 & 2013 & 2012 & 2013 & 2012 & 2013 \\
EM at $60 \mathrm{ml} / \mathrm{palm}$ & $3.66 \mathrm{~d}$ & $3.42 \mathrm{~g}$ & $2.20 \mathrm{~d}$ & $2.11 \mathrm{~d}$ & $7.1 \mathrm{f}$ & $6.75 \mathrm{f}$ \\
$\mathrm{EM}$ at $90 \mathrm{ml} / \mathrm{palm}$ & $3.73 \mathrm{~cd}$ & $3.54 \mathrm{fg}$ & $2.25 \mathrm{~cd}$ & $2.15 \mathrm{~cd}$ & $7.8 \mathrm{ef}$ & $7.32 \mathrm{ef}$ \\
$\mathrm{K}_{2} \mathrm{SO}_{4}$ at $1 \mathrm{~kg} / \mathrm{palm}$ & $3.82 \mathrm{~cd}$ & $3.60 \mathrm{efg}$ & $2.42 \mathrm{ab}$ & $2.17 \mathrm{~cd}$ & $8.5 \mathrm{de}$ & $7.99 \mathrm{e}$ \\
$\mathrm{K}_{2} \mathrm{SO}_{4}$ at $1.5 \mathrm{~kg} / \mathrm{palm}$ & $3.81 \mathrm{~cd}$ & $3.61 \mathrm{def}$ & $2.33 \mathrm{bcd}$ & $2.16 \mathrm{~cd}$ & $8.0 \mathrm{ef}$ & $7.56 \mathrm{ef}$ \\
$\mathrm{EM}$ at $60 \mathrm{ml}+\mathrm{K}_{2} \mathrm{SO}_{4}$ at $1 \mathrm{~kg} / \mathrm{palm}$ & $3.97 \mathrm{bc}$ & $3.76 \mathrm{cde}$ & $3.35 \mathrm{bc}$ & $2.25 \mathrm{bc}$ & $9.1 \mathrm{~d}$ & $9.98 \mathrm{~d}$ \\
$\mathrm{EM}$ at $90 \mathrm{ml}+\mathrm{K}_{2} \mathrm{SO}_{4}$ at $1 \mathrm{~kg} / \mathrm{palm}$ & $4.11 \mathrm{ab}$ & $3.78 \mathrm{~cd}$ & $2.44 \mathrm{ab}$ & $2.31 \mathrm{ab}$ & $10.8 \mathrm{c}$ & $10.03 \mathrm{c}$ \\
$\mathrm{EM}$ at $60 \mathrm{ml}+\mathrm{K}_{2} \mathrm{SO}_{4}$ at $1.5 \mathrm{~kg} / \mathrm{palm}$ & $4.15 \mathrm{ab}$ & $3.89 \mathrm{bc}$ & $2.45 \mathrm{ab}$ & $2.33 \mathrm{ab}$ & $11.0 \mathrm{c}$ & $10.50 \mathrm{c}$ \\
$\mathrm{EM}$ at $90 \mathrm{ml}+\mathrm{K}_{2} \mathrm{SO}_{4}$ at $1.5 \mathrm{~kg} / \mathrm{palm}$ & $3.95 \mathrm{bc}$ & $3.96 \mathrm{ab}$ & $2.51 \mathrm{a}$ & $2.39 \mathrm{a}$ & $12.3 \mathrm{~b}$ & $11.71 \mathrm{~b}$ \\
\hline
\end{tabular}

Means within each column followed by the same letter (s) are not significantly different at $5 \%$ level.

Table 6. Effect of EM and potassium sulphate soil application on some fruit physical and chemical properties of "Hayany" date palms ( 2012 \&2013 seasons)

\begin{tabular}{|c|c|c|c|c|c|c|}
\hline \multirow[t]{2}{*}{ Treatments } & \multicolumn{2}{|c|}{ Pulp dry matter (\%) } & \multicolumn{2}{|c|}{ Seed weight $(\mathrm{g})$} & \multicolumn{2}{|c|}{ T.S.S $(\%)$} \\
\hline & 2012 & 2013 & 2012 & 2013 & 2012 & 2013 \\
\hline Control " untreated" & $36.4 \mathrm{c}$ & $36.3 \mathrm{~b}$ & $1.36 \mathrm{c}$ & $1.28 \mathrm{~b}$ & $28.4 \mathrm{c}$ & $28.4 \mathrm{e}$ \\
\hline $\mathrm{EM}$ at $60 \mathrm{ml} / \mathrm{palm}$ & $36.4 \mathrm{c}$ & $36.4 \mathrm{~b}$ & $1.28 \mathrm{c}$ & $1.33 \mathrm{~b}$ & $29.8 \mathrm{~d}$ & $29.3 \mathrm{~d}$ \\
\hline $\mathrm{EM}$ at $90 \mathrm{ml} / \mathrm{palm}$ & $36.7 \mathrm{c}$ & $36.6 \mathrm{ab}$ & $1.52 \mathrm{bc}$ & $1.43 \mathrm{~b}$ & $30.6 \mathrm{~cd}$ & $30.3 \mathrm{c}$ \\
\hline $\mathrm{K}_{2} \mathrm{SO}_{4}$ at $1 \mathrm{~kg} / \mathrm{palm}$ & $36.6 \mathrm{c}$ & $36.4 \mathrm{~b}$ & $1.48 \mathrm{bc}$ & $1.41 \mathrm{~b}$ & $30.7 \mathrm{~cd}$ & $30.3 \mathrm{c}$ \\
\hline $\mathrm{K}_{2} \mathrm{SO}_{4}$ at $1.5 \mathrm{~kg} / \mathrm{palm}$ & $36.8 \mathrm{c}$ & $36.7 \mathrm{ab}$ & $1.67 \mathrm{ab}$ & $1.50 \mathrm{~b}$ & $31.2 \mathrm{bc}$ & $30.9 \mathrm{~b}$ \\
\hline $\mathrm{EM}$ at $60 \mathrm{ml}+\mathrm{K}_{2} \mathrm{SO}_{4}$ at $1 \mathrm{~kg} / \mathrm{palm}$ & $36.9 \mathrm{c}$ & $36.9 \mathrm{ab}$ & $5.77 \mathrm{bc}$ & $1.47 \mathrm{a}$ & $31.8 \mathrm{abc}$ & $31.1 \mathrm{~b}$ \\
\hline $\mathrm{EM}$ at $90 \mathrm{ml}+\mathrm{K}_{2} \mathrm{SO}_{4}$ at $1 \mathrm{~kg} / \mathrm{palm}$ & $37.3 \mathrm{bc}$ & $36.9 \mathrm{ab}$ & $1.90 \mathrm{a}$ & $1.40 \mathrm{~b}$ & $32.3 \mathrm{ab}$ & $31.3 \mathrm{~b}$ \\
\hline $\mathrm{EM}$ at $60 \mathrm{ml}+\mathrm{K}_{2} \mathrm{SO}_{4}$ at $1.5 \mathrm{~kg} / \mathrm{palm}$ & $38.3 \mathrm{ab}$ & $37.6 \mathrm{ab}$ & $1.47 \mathrm{bc}$ & $1.76 \mathrm{a}$ & $32.7 \mathrm{a}$ & $31.9 \mathrm{a}$ \\
\hline $\mathrm{EM}$ at $90 \mathrm{ml}+\mathrm{K}_{2} \mathrm{SO}_{4}$ at $1.5 \mathrm{~kg} / \mathrm{palm}$ & $39.3 \mathrm{a}$ & $38.8 \mathrm{a}$ & $1.43 \mathrm{bc}$ & $1.41 \mathrm{~b}$ & $32.9 \mathrm{a}$ & $32.4 \mathrm{a}$ \\
\hline
\end{tabular}

Means within each column followed by the same letter (s) are not significantly different at $5 \%$ level.

\subsubsection{Fruit Total acidity content $(\%)$}

Tabulated data demonstrate that all tested treatments induced a pronounced reduction effect on fruit total acidity content as compared with the control treatment. Briefly, $90 \mathrm{ml} / \mathrm{palm}$ EM combined with potassium sulphate at $1.5 \mathrm{~kg} / \mathrm{palm}$ proved to be the most efficient treatment in reducing fruit total acidity content in both seasons. 


\subsubsection{Fruit T.S.S. / Acid ratio}

Table 7, indicates that all tested treatments scored significantly higher values of fruit TSS/acid ratio as compared with control treatment in both seasons of study. Generally, $90 \mathrm{ml} / \mathrm{palm}$ EM combined with potassium sulphate at $1.5 \mathrm{~kg} / \mathrm{palm}$ treatment proved to be the most efficient treatment (182.7 and 202.5) against (97.9 and 101.4) from the control treatment in first and second seasons, respectably .

Table 7. Effect of EM and potassium sulphate soil application on some fruit chemical properties of "Hayany" date palms (2012 \&2013 seasons)

\begin{tabular}{|c|c|c|c|c|c|c|}
\hline \multirow[t]{2}{*}{ Treatments } & \multicolumn{2}{|c|}{ Total acidity $(\%)$} & \multicolumn{2}{|c|}{ T.S.S./acid ratio } & \multicolumn{2}{|c|}{ Total sugars (\%) } \\
\hline & 2012 & 2013 & 2012 & 2013 & 2012 & 2013 \\
\hline Control " untreated" & $0.29 \mathrm{a}$ & $0.28 \mathrm{a}$ & $97.9 \mathrm{i}$ & $101.4 \mathrm{i}$ & $23.2 \mathrm{e}$ & $23.3 \mathrm{f}$ \\
\hline $\mathrm{EM}$ at $60 \mathrm{ml} / \mathrm{palm}$ & $0.26 \mathrm{~b}$ & $0.26 \mathrm{~b}$ & $114.6 \mathrm{~h}$ & $112.6 \mathrm{~h}$ & $24.6 \mathrm{~d}$ & $25.2 \mathrm{e}$ \\
\hline $\mathrm{EM}$ at $90 \mathrm{ml} / \mathrm{palm}$ & $0.24 \mathrm{c}$ & $0.25 \mathrm{bc}$ & $127.5 \mathrm{~g}$ & $121.2 \mathrm{~g}$ & $25.6 \mathrm{c}$ & $26.1 \mathrm{de}$ \\
\hline $\mathrm{K}_{2} \mathrm{SO}_{4}$ at $1 \mathrm{~kg} / \mathrm{palm}$ & $0.23 \mathrm{~d}$ & $0.24 \mathrm{c}$ & $133.4 \mathrm{f}$ & $126.2 \mathrm{f}$ & $25.8 \mathrm{c}$ & $26.8 \mathrm{~d}$ \\
\hline $\mathrm{K}_{2} \mathrm{SO}_{4}$ at $1.5 \mathrm{~kg} / \mathrm{palm}$ & $0.22 \mathrm{~d}$ & $0.23 \mathrm{~d}$ & $141.8 \mathrm{e}$ & $134.3 \mathrm{e}$ & $26.0 \mathrm{c}$ & $28.1 \mathrm{c}$ \\
\hline $\mathrm{EM}$ at $60 \mathrm{ml}+\mathrm{K}_{2} \mathrm{SO}_{4}$ at $1 \mathrm{~kg} / \mathrm{palm}$ & $0.22 \mathrm{~d}$ & $0.21 \mathrm{e}$ & $144.5 \mathrm{~d}$ & $147.6 \mathrm{~d}$ & $28.9 \mathrm{~b}$ & $28.9 \mathrm{bc}$ \\
\hline $\mathrm{EM}$ at $90 \mathrm{ml}+\mathrm{K}_{2} \mathrm{SO}_{4}$ at $1 \mathrm{~kg} / \mathrm{palm}$ & $0.19 \mathrm{e}$ & $0.19 \mathrm{f}$ & $170.0 \mathrm{c}$ & $164.7 \mathrm{c}$ & $28.9 \mathrm{~b}$ & $29.6 \mathrm{ab}$ \\
\hline $\mathrm{EM}$ at $60 \mathrm{ml}+\mathrm{K}_{2} \mathrm{SO}_{4}$ at $1.5 \mathrm{~kg} / \mathrm{palm}$ & $0.19 \mathrm{e}$ & $0.18 \mathrm{f}$ & $172.1 \mathrm{~b}$ & $177.2 \mathrm{~b}$ & $29.3 \mathrm{ab}$ & $30.2 \mathrm{a}$ \\
\hline $\mathrm{EM}$ at $90 \mathrm{ml}+\mathrm{K}_{2} \mathrm{SO}_{4}$ at $1.5 \mathrm{~kg} / \mathrm{palm}$ & $0.18 \mathrm{f}$ & $0.16 \mathrm{~g}$ & $182.7 \mathrm{a}$ & $202.5 \mathrm{a}$ & $29.9 \mathrm{a}$ & $30.7 \mathrm{a}$ \\
\hline
\end{tabular}

Means within each column followed by the same letter (s) are not significantly different at 5\% level.

\subsubsection{Fruit total sugars content}

Table 7, reveals that $90 \mathrm{ml} /$ palm EM combined with potassium sulphate at $1.5 \mathrm{~kg} / \mathrm{palm}$ in the first season as well as 60 and $90 \mathrm{ml} /$ palm EM combined with potassium sulphate at $1.5 \mathrm{~kg} / \mathrm{palm}$ treatments produced high positive effect on fruit total sugar content as compared with control treatment. Other tested treatments surpassed the control treatment in enhancing fruit total sugar content in both seasons.

The enhancement effect of EM application on alleviating the detrimental effect of salinity on fruit physical and chemical properties may be due to increasing leaf total chlorophyll content which reflected on improving vegetative growth which leads to more carbohydrates production through photosynthesis process. Moreover, EM application increased number of the soil microflora i.e. total bacteria, total actinomyces and total fungi which are precursors of indole acetic acid and gibberellins leads to improvement growth of root system that reflected on enhancing the uptake of nutrients, thereby improving plant health under salinity stress and improved fruit quality (Higa, 1991).

The obtained results of EM application regarding their positive effect on fruit physical and chemical properties are in harmony with the findings of Osman et al. (2011) on "Bartamuda" date palm El-Khawaga (2013) on date palm cultivars "Sewy", "Zaghloul" and "Hayany".

The enhancement effect of sulphate application on alleviating the negative effect of salinity on fruit physical and chemical properties may be due to that potassium has an essential role in photosynthesis and osmoregulatory (Nelson, 1978), and it is required for physiological processes such as activation of enzymes, regulation of osmotic pressure and stomata movement (Gollback et al., 2003).As well as, it activates the enzymes involved in sugar biosynthesis and helps in translocation of sugars (Archer, 1988). Moreover, potassium shows an important role in controlling cell water content and carbohydrates biosynthesis and mobilization in plant tissues.

The obtained results regarding the effect of potassium sulphate application on fruit physical and chemical properties go in line with the findings of Harhash and Abdel-Nasser (2007) on date palm cultivar "Zaghloul"; Shahin (2007) on date palm cultivar "Khalas"; Harhash and Abdel-Nasser (2010) on date palm cultivar "Khalas"; Osman (2010) on date palm cultivar " Bartamoda"; Al-Obeed et al. (2013) on date palm cultivar "Khalas"; Abdelaal et al. (2013) on "Valencia"orange.

\subsection{Leaf minerals content}

3.6.1. Nitrogen $(\%)$

Table 8, indicates that all tested treatments significantly increased the leaf nitrogen content of "Hayany" date palms as compared with the control treatment in both seasons of study. However, $90 \mathrm{ml} / \mathrm{palm}$ EM combined with potassium sulphate at $1.5 \mathrm{~kg} / \mathrm{palm}$ treatment recorded the highest values in this respect.

\subsubsection{Phosphorus (\%)}

Table 8, shows that $60 \mathrm{ml} / \mathrm{palm} \mathrm{EM}$ and/or in combination with potassium sulphate at 1 and $1.5 \mathrm{~kg} / \mathrm{palm}$ and $90 \mathrm{ml} / \mathrm{palm} \mathrm{EM}$ and/or supported with potassium sulphate at 1 and $1.5 \mathrm{~kg} / \mathrm{palm}$ treatments as well as potassium sulphate at $1.5 \mathrm{~kg} / \mathrm{palm}$ treatment gave a similar and higher positive effect on leaf phosphorus content in the first seasons. On the other hand, $90 \mathrm{ml} / \mathrm{palm}$ EM provided with potassium sulphate at $1.5 \mathrm{~kg} / \mathrm{palm}$ treatment gave the highest positive effect on leaf phosphorus content in the second season. 
Table 8. Effect of EM and potassium sulphate soil application on leaf minerals content of "Hayany" date palms (2012 \&2013 seasons)

\begin{tabular}{|c|c|c|c|c|c|c|}
\hline \multirow[t]{2}{*}{ Treatments } & \multicolumn{2}{|c|}{ Nitrogen $(\%)$} & \multicolumn{2}{|c|}{ Phosphorus $(\%)$} & \multicolumn{2}{|c|}{ Potassium (\%) } \\
\hline & 2012 & 2013 & 2012 & 2013 & 2012 & 2013 \\
\hline Control " untreated" & $1.24 \mathrm{~h}$ & $1.25 \mathrm{~g}$ & $0.15 \mathrm{c}$ & $0.14 \mathrm{e}$ & $0.53 \mathrm{f}$ & $0.54 \mathrm{~g}$ \\
\hline $\mathrm{EM}$ at $60 \mathrm{ml} / \mathrm{palm}$ & $1.32 \mathrm{~g}$ & $1.34 \mathrm{f}$ & $0.16 \mathrm{bc}$ & $0.16 \mathrm{de}$ & $0.57 \mathrm{e}$ & $0.58 \mathrm{f}$ \\
\hline $\mathrm{EM}$ at $90 \mathrm{ml} / \mathrm{palm}$ & $1.44 \mathrm{e}$ & $1.44 \mathrm{de}$ & $0.18 \mathrm{~b}$ & $0.17 \mathrm{de}$ & $0.66 \mathrm{~d}$ & $0.65 \mathrm{e}$ \\
\hline $\mathrm{K}_{2} \mathrm{SO}_{4}$ at $1 \mathrm{~kg} / \mathrm{palm}$ & $1.37 \mathrm{f}$ & $1.39 \mathrm{ef}$ & $0.17 \mathrm{bc}$ & $0.17 \mathrm{de}$ & $0.65 \mathrm{~d}$ & $0.64 \mathrm{e}$ \\
\hline $\mathrm{K}_{2} \mathrm{SO}_{4}$ at $1.5 \mathrm{~kg} / \mathrm{palm}$ & $1.47 \mathrm{e}$ & $1.46 \mathrm{~d}$ & $0.21 \mathrm{a}$ & $0.20 \mathrm{c}$ & $0.65 \mathrm{~d}$ & $0.66 \mathrm{de}$ \\
\hline $\mathrm{EM}$ at $60 \mathrm{ml}+\mathrm{K}_{2} \mathrm{SO}_{4}$ at $1 \mathrm{~kg} / \mathrm{palm}$ & $1.56 \mathrm{~d}$ & $1.55 \mathrm{c}$ & $0.21 \mathrm{a}$ & $0.21 \mathrm{bc}$ & $0.68 \mathrm{~cd}$ & $0.69 \mathrm{~cd}$ \\
\hline $\mathrm{EM}$ at $90 \mathrm{ml}+\mathrm{K}_{2} \mathrm{SO}_{4}$ at $1 \mathrm{~kg} / \mathrm{palm}$ & $1.69 \mathrm{c}$ & $1.67 \mathrm{~b}$ & $0.22 \mathrm{a}$ & $0.22 \mathrm{abc}$ & $0.70 \mathrm{c}$ & $0.71 \mathrm{bc}$ \\
\hline $\mathrm{EM}$ at $60 \mathrm{ml}+\mathrm{K}_{2} \mathrm{SO}_{4}$ at $1.5 \mathrm{~kg} / \mathrm{palm}$ & $1.73 \mathrm{~b}$ & $1.70 \mathrm{~b}$ & $0.22 \mathrm{a}$ & $0.23 \mathrm{ab}$ & $0.75 \mathrm{~b}$ & $0.74 \mathrm{~b}$ \\
\hline $\mathrm{EM}$ at $90 \mathrm{ml}+\mathrm{K}_{2} \mathrm{SO}_{4}$ at $1.5 \mathrm{~kg} / \mathrm{palm}$ & $1.79 \mathrm{a}$ & $1.77 \mathrm{a}$ & $0.23 \mathrm{a}$ & $0.24 \mathrm{a}$ & $0.85 \mathrm{a}$ & $0.86 \mathrm{a}$ \\
\hline
\end{tabular}

Means within each column followed by the same letter (s) are not significantly different at $5 \%$ level.

\subsubsection{Potassium $(\%)$}

Table 8, illustrates that all tested EM and potassium sulphate treatments induced high positive effect on leaf potassium content than the control treatment in both seasons. Generally, $90 \mathrm{ml} / \mathrm{palm}$ EM combined with potassium sulphate at $1.5 \mathrm{~kg} / \mathrm{palm}$ treatment proved to be the most efficient treatments in this concern.

\subsubsection{Calcium $(\%)$}

Table 9, indicates that $90 \mathrm{ml} / \mathrm{palm}$ EM provided with potassium sulphate at $1.5 \mathrm{~kg} / \mathrm{palm}$ treatment in the first season whereas 60 and $90 \mathrm{ml} / \mathrm{palm}$ EM supplemented with $1.5 \mathrm{~kg} /$ palm treatments in the second season gave higher positive effect on leaf calcium content.

\subsubsection{Magnesium (\%)}

Table 9 , shows that $90 \mathrm{ml} / \mathrm{palm}$ EM and/or supported with potassium sulphate at $1.5 \mathrm{~kg} / \mathrm{palm}$ treatments in the first season and 60 and $90 \mathrm{ml} / \mathrm{palm} \mathrm{EM}$ and/or enriched with potassium sulphate at $1.5 \mathrm{~kg} / \mathrm{palm}$ treatments in the second one gave similar and higher positive effect on leaf magnesium content as compared with the control treatment.

Table 9. Effect of EM and potassium sulphate soil application on leaf minerals contents of "Hayany" date palms (2012 \&2013 seasons)

\begin{tabular}{lllll}
\multicolumn{1}{c}{ Treatments } & \multicolumn{2}{c}{ Calcium (\%) } & \multicolumn{2}{l}{ Magnesium (\%) } \\
\hline Control " untreated" & 2012 & 2013 & 2012 & 2013 \\
EM at $60 \mathrm{ml} / \mathrm{palm}$ & $0.43 \mathrm{~d}$ & $0.48 \mathrm{f}$ & $0.25 \mathrm{~d}$ & $0.26 \mathrm{e}$ \\
$\mathrm{EM}$ at $90 \mathrm{ml} / \mathrm{palm}$ & $0.46 \mathrm{~cd}$ & $0.50 \mathrm{e}$ & $0.28 \mathrm{~cd}$ & $0.27 \mathrm{de}$ \\
$\mathrm{K}_{2} \mathrm{SO}_{4}$ at $1 \mathrm{~kg} / \mathrm{palm}$ & $0.48 \mathrm{c}$ & $0.52 \mathrm{~cd}$ & $0.31 \mathrm{bc}$ & $0.31 \mathrm{~cd}$ \\
$\mathrm{~K}_{2} \mathrm{SO}_{4}$ at $1.5 \mathrm{~kg} / \mathrm{palm}$ & $0.54 \mathrm{~b}$ & $0.51 \mathrm{de}$ & $0.29 \mathrm{bc}$ & $0.28 \mathrm{de}$ \\
$\mathrm{EM}$ at $60 \mathrm{ml}+\mathrm{K}_{2} \mathrm{SO}_{4}$ at $1 \mathrm{~kg} / \mathrm{palm}$ & $0.57 \mathrm{ab}$ & $0.53 \mathrm{c}$ & $0.33 \mathrm{~b}$ & $0.34 \mathrm{c}$ \\
$\mathrm{EM}$ at $90 \mathrm{ml}+\mathrm{K}_{2} \mathrm{SO}_{4}$ at $1 \mathrm{~kg} / \mathrm{palm}$ & $0.57 \mathrm{ab}$ & $0.53 \mathrm{c}$ & $0.39 \mathrm{a}$ & $0.38 \mathrm{~b}$ \\
$\mathrm{EM}$ at $60 \mathrm{ml}+\mathrm{K}_{2} \mathrm{SO}_{4}$ at $1.5 \mathrm{~kg} / \mathrm{palm}$ & $0.57 \mathrm{ab}$ & $0.55 \mathrm{~b}$ & $0.40 \mathrm{a}$ & $0.41 \mathrm{ab}$ \\
EM at $90 \mathrm{ml}+\mathrm{K}_{2} \mathrm{SO}_{4}$ at $1.5 \mathrm{~kg} / \mathrm{palm}$ & $0.58 \mathrm{ab}$ & $0.57 \mathrm{a}$ & $0.41 \mathrm{a}$ & $0.43 \mathrm{a}$ \\
\hline
\end{tabular}

Means within each column followed by the same letter (s) are not significantly different at $5 \%$ level.

The enhancement effect of EM on alleviating the detrimental effect of salinity on leaf minerals content may be attributed to the fact that EM have beneficial effect on lowering soil $\mathrm{pH}$, and increasing the uptake of water and nutrients (Higa, 1991; Higa and Wididana, 1991), and enhancing soil fertility (Formowitz et al., 2007 and Ibrahim, 2012). Moreover, EM application increased number of the soil microflora i.e. total bacteria, total actinomyces and total fungi which are the producers of indole acetic acid and gibberellins leads to improvement growth of root system that reflected on enhanced the uptake of nutrients, thereby improving plant health under salinity stress consequently improved leaf mineral content (Higa, 1991).

The enhancement effect of potassium sulphate on alleviating the negative effect of salinity on leaf minerals content may be due to that potassium reduces the excess uptake of ions such as sodium under saline stress. Also, potassium plays a key role in $\mathrm{N}$ uptake and translocation from roots to vegetative growth (Cushnahan et al., 1995). Consequently leads to enhanced the uptake of nutrients from soil.

The obtained results regarding the effect of EM and potassium sulphate application on leaf mineral content are in line with the findings of Abdelaal et al. (2013) on "Valencia" orange.

Briefly, from the obtained results and under similar conditions it is preferable to add EM at $90 \mathrm{ml} /$ $\mathrm{palm} /$ year enriched with potassium sulphate at $1.5 \mathrm{~kg} / \mathrm{palm} /$ year treatment as soil application to alleviate salinity 
stress and enhance leaf chlorophyll content, retained fruit percentage, yield, fruit quality and leaf minerals content of "Hayany" date palm.

\section{Reference}

[1]. A.O.A.C. 1995. Association of Official Agricultural Chemists, Official Methods of Analysis, 15th ed. A.O.A.C., Washington, DC.

[2]. Abdelaal, H. M.; Faissal F. A. ; El- Masry, S.E.M.A. and Abdallah, A. A., 2013. Using Potassium Sulphur as Well as Organic and Biofertilization for Alleviating The Adverse Effects of Salinity on Growth and Fruiting of Valencia Orange Trees. Stem Cell, 4(4):27-32.

[3]. Al- Abdoulhadi, I. A. ; Dinar, H. A.; Ebert, G. and Buttner, C., 2012. Infulence of salinity stress on photosynthesis and chlorophyll content in date palm (Phoenix dactilfera L.) cultivars. African Journal of Agriculture Research Vol. 7(22):3314-3319.

[4]. Allahverdiyev, S.; Atilla, A.; Ismail, B. S. and Sahmurova, A., 2011. Response of photosystem II and photosynthetic pigments to salt and Baikal EM1 in tree seedlings. African Journal of Biotechnology Vol. 10 (4), pp. 535-538.

[5]. Al-Obeed, R. S.; Kassem, H.A. and Ahmed, M.A., 2013. Effect of Levels and Methods of Potassium and Phosphorus Fertilization on Yield, Fruit Quality and Chemical Composition of "Khalas” Date Palm Cultivar. Life Science Journal, 10(4):1111-1118.

[6]. Archer, J.R., 1988. Crop Nutrition and Fertilizer Use. Farming Press Ltd. 2nd Revised edition. 278 pp. ISBN-10: 0852361750

[7]. Ashraf, M., 2004. Some important physiological selection criteria for salt tolerance. Flora., 199: 361-376.

[8]. Ayers, R.S. and Westcot, D.W., 1985. FAO irrigation and drainage paper 29 Rev. 1, Water quality for agriculture.

[9]. Bremner, J.M., 1965. Total nitrogen. In: Methods of Soil Analysis (Part 2). Black, C.A. (Ed), pp: 1149-78. American Society of Agronomy, Madison, USA.

[10]. Cakmak, I., 2005. The role of potassium in alleviating detrimental effects of abiotic stresses in plants. J. Plant Nutr. Soil Sci., 168: 521-530.

[11]. Chamberlain, T.P.; Daly, M.J. and Merfield, C.N., 1997. Utilization of Effective Microorganisms in Commercial Organic Agriculture: A Case Study from New Zealand. Proc. 5th International Kyusei Nature Farming Conference, pp: 120-123. Bangkok, Thailand

[12]. Chapman, H. D. and Pratt, P. F., 1961. Methods of Analysis for Soils, Plants and Water. University of California Division of Agricultural Sciences.

[13]. Clarke, G. M. and Kempson, R. E., 1997. Introduction to the design and analysis of experiments. Arnold, a Member of the Holder Headline Group, 1st Edt. London, UK.

[14]. Cushnahan A.; Bailey, J.S. and Gordon, F.J., 1995.Some effects of sodium application on the yield and chemical composition of pasture grass under differing conditions of potassium and moisture supply. Plant Soil 176:117-127.

[15]. Dong, S.; Cheng, L.; Scagel, C.F. and Fuchigami, L.H., 2005. Timing of urea application affects leaf and root N uptake in young Fuji/M9 apple trees. J. Hortic. Sci. Biotech., 80: 116-120.

[16]. Duncan, D. B., 1955. Multiple range and multiple F Test. Biometrics, 11: 1-42.

[17]. El- Deeb M.D.; Sourour M.M.and Ismail S.A., (2000) Use of Olive Pomace and Mineral Fertilizers for Hayany Date Palm Fertilization. In 'Proceedings of Date Palm International Symposium, Windhoek, Namibia'.

[18]. El-Khawaga A.S., 2013. Effect of anti-salinity agents on growth and fruiting of different date palm cultivars. Asian Journal of Crop Science 5(1):65-80.

[19]. Erskine, W.; Moustafa, A. T.; Osman, A. E.; Lashine, Z.; Nejatian, A. ; Badawi, T. and Ragy, S.M. 2004. Date palm in the GCC countries of the Arabian Peninsula. In: Regional Workshop on Date palm Development in the Arabian Peninsula, Abu Dhabi. UAE.

[20]. FAO, 1982. Plant Production and Protection Paper. Date Production and Protection. Food and Agriculture Organization of the United Nation. Rome, Italy.

[21]. Formowitz, B.; Elango, F.; Okumoto, S.; Miiller, T. and Buerert, A., 2007. The role of effective microorganisms in the compositing of banana (Musa spp.) residues. J. of Plant Nutrition and Soil Sci., 170: Issue 5 pp 649 - 656.

[22]. Gollback, D.; Quigley, F.; Michalowski, C.B. ; Kamasani, U.R. and Bohnert, H. J., 2003. Salinity tolerant and sensitive rice (Oryza sativa L.,) regulate AFT1-Type potassium channel transcripts differently. Plant Mol. Biol., 51(1):71-81.

[23]. Gunes, A.; Inal, A.; Alpaslan, M.; Eraslan, F.; Bagci, E.G. and Cicek, N., 2007. Salicylic acid induced changes on some physiological parameters symptomatic for oxidative stress and mineral nutrition in maize (Zea mays L.) grown under salinity. J. Plant Physiol., 164: 728-736.

[24]. Harhash, M.M. and Abdel-Nasser, G., 2007. Impact of Potassium Fertilization and Bunch Thinning on Zaghloul Date Palm. The Fourth Symposium on Date Palm in Saudi Arabia (Challenges of Processing, Marketing, and Pests Control), Date Palm Research Center, King Faisal University, Al-Hassa. 5-8 May, 2007. Abstracts Book, page 70.

[25]. Harhash, M.M. and Abdel-Nasser, G., 2010. Improving of fruit set, yield and fruit quality of "Khalas" tissue culture derived date palm through bunches spraying with potassium and/or boron. Australian Journal of Basic and Applied Sciences, 4(9): 4164-4172, 2010 ISSN 1991-8178

[26]. Hassan M.M. and El-Samnoudi, 1998. Salt tolerance of date palm trees. Proceedings of the third International Symposium on Date Palm, King Faisal University, Al-Hassa, Saudi Arabia, pp.293-297.

[27]. Higa, T., 1986. Studies on the application of effective microorganisms in nature farming. 6th IFOAM Conference, Aug. 18-21, 1986, California University. Tung, P. G. A.; Yusoff, M. K.; Majid, N. M.; Joo, G.K. and G. H. Huang (2009). Effect of N and K fertilizers on nutrient leaching and groundwater quality under mature oil palm in Sabah during the monsoon period.Amer. J. Applied Sci. Article. Date.

[28]. Higa, T., 1991. Effective microorganisms: A biotechnology for mankind. In: Parr, J.F., S.B. Hornick and C.E. Whitman (eds.), Proc First International Conference on Kyusei Nature Farming, pp: 8-14. U.S. Department of Agriculture, Washington, DC

[29]. Higa, T. and Wididana, G.N., 1991. The concept and theories of Effective Microorganisms. In: Parr, J.F., S.B. Hornick and C.E. Whitman (eds.), Proc. First International Conference on Kyusei Nature Farming, US Department of Agriculture, Washington, D.C., pp: $118-124$.

[30]. Ibrahim, W. M. A., 2012. Behaviour of Taimour mango trees to inorganic and organic fertilization and application of EM. Ph. D. Thesis, Fac. of Agric. Minia Univ., Egypt.

[31]. Jackson, M.L., 1958. Soil Chemical Analysis. P. 498. Constable Ltd. Co., London.

[32]. Khayyat, M.; Tafazoli, E.; Eshghi, S. and Rajaee, S., 2007. Effect of Nitrogen, Boron, Potassium and Zinc on Yield and Fruit Quality of Date Palm. American-Eurasian J. Agric. \& Environ. Sci., 2(3): 289-296. ISSN:1818-6769.

[33]. Lunde P., 1978. A History of Dates. Saudi Aramco World, 29, 2, 176-179.

[34]. Maathuis, F. and Amtmann, A., 1999. K+ nutrition and Na+ toxicity: the basis of cellular K+/Na+ ratios. Ann. Bot., 84:123-133. 
[35]. Marschner H., 1993. Mineral Nutrition of Higher Plants. 2nd edition. (Academic Press: Harcourt and Brace Company, London, UK).

[36]. Marschner, H., 1995. Mineral Nutrition of Higher Plants. Academic Press, London. ISBN: 0124735436. Mengel, K. and E.A. Kirkby, 2001. Principles of Plant Nutrition. 5th rev ed., Kluwer Academic Publishers (United States). ISBN-10: 1402000081.

[37]. Mengel, K. and Kirkby, E.A. 2001. Principles of Plant Nutrition.5th ed., Kluwer Academic Publishers, Dordrecht.

[38]. Mittler, R., 2002. Oxidative stress, antioxidants and stress tolerance. Trends Plant Sci., 7: 405-410.

[39]. Mstat-C, 1990.A micro computer Program for Design, Management and Analysis of Agronomic Research Experiments. Michigan Stat University.

[40]. Nelson, W.L., 1978. Inflence of K on tolerance to stress (North American Experience). pp: 203-2011. In: G.S. Sekhon. (Ed.) Potassium in Soils and Crops . Potash Res. Inst. of India. New Delhi.

[41]. Osman, S.M., 2010. Effect of Potassium Fertilization on Yield, Leaf Mineral Content and Fruit Quality of Bartamoda Date Palm Propagated by Tissue Culture Technique under Aswan Conditions. Journal of Applied Sciences Research, 6(2): 184-190, 2010

[42]. Osman, S. O.A.; Moustafa, F. M. A.; Abd El- Galil, H. A. and Ahmed, A.Y.M., 2011. Effect of yeast and Effective Microorganisms (Em1) application on the yield and fruit characteristics of Bartamuda date palm under Aswan conditions. Assiut J. of Agric. Sci., 42 (Special Issue )(The 5th Conference of Young Scientists Fac. of Agric. Assiut Univ. May,8, 2011) (332-349)

[43]. Parkinson, J.A. and Allen, S. E., 1975. A wet oxidation procedure suitable for the determination of nitrogen and mineral nutrients in biological material. Commun. Soil Sci. and Plant Analysis, 6(1): 1-11.

[44]. Parida, A. K. and Das, A. B., 2005. Salt tolerance and salinity effects on plants: A review. Ecotoxicology Environmental Safety, 60(3): 324-349.Pessarakli, M. and Szabolcs, I. 2010. Soil salinity and Sodicity as Particular Plant/Crop Stress Factors. In: Pessarakli, M. 2010. Handbook of Plant and Crop Stress. Pp 3-15. 3rd Eddition. CRC Press. Florida, USA.

[45]. Ramoliya, P.J. and Pandey, A. N., 2003. Soil salinity and water status affect growth of Phoenix dactylifera seedlings. N.Z.J. Crop Hortic. 31: 345-353.

[46]. Shahin, M., 2007. Effect of Potassium Fertilization on Growth, Leaves Nutrient Content, and Yield of "Khalas" Date Palm in AlHassa Oasis (K.S.A). The Fourth Symposium on Date Palm in Saudi Arabia (Challenges of Processing, Marketing, and Pests Control), Date Palm Research Center, King Faisal University, Al-Hassa. 5-8 May, 2007. Abstracts Book, pp: 77

[47]. Soliman, S.S. and El Kosary, S., 2002. Effect of different hand pollination methods on fruit retained, yield and fruit quality of some Egyptian date palm cultivars. Egypt. J. Hort., 29(2): 281-300

[48]. Zaid, A. and De Wet, P.F., 2002. Climatic requirements of date palm. In: A. Zaid (ed.).Date palm cultivation. Food and AgricultureOrganization. Plant Production and Protection Paper No. 156. Food and Agriculture Organization of the United Nations, Rome, Italy, pp. 57-72.

[49]. Zheng, Y.; Aijun, J.; Tangyuan, N.; Jialin, X.; Zengjia, L. and Gaoming, J., 2008. Potassium nitrate application alleviates sodium chloride stress in winter wheat cultivars differing in salt tolerance. J. Plant Physiol., 165: 1455-1465. 